\title{
The Education of Minority Muslim Students: Comparative Perspective
}

\author{
Marie McAndrew • Julia Ipgrave • \\ Amina Triki-Yamani
}

Published online: 29 January 2010

(C) Springer Science+Business Media B.V. 2010

\section{Introduction}

Education plays a major role in the production and redefinition of ethnic and cultural boundaries, through its three basic mandates (Holmes 1981; Ballantyne 1989): linguistic and cultural reproduction; formal and informal socialization; and the selection and allocation of future human resources. In the first instance, one often witnesses a competition between majority and minority groups in order to maximize the benefits of schooling for the preservation of their defining markers, as exemplified by the numerous controversies in different contexts regarding the role of language, culture and religion in the curriculum (Krashen 1996; McAndrew 2001). Schools also play a central role in the formation of identities and attitudes among youth as well as in the sharing of common values, both at the national level and within minority groups. In this regard, radically divergent conceptions of citizenship lead to highly divergent views about, for example, the respective relevance of common schooling or of the attendance of specific institutions by ethnic minorities (Homan 1992; Dei et al. 2000). Finally, even if there is a high consensus on the necessity for schools to ensure equal treatment and outcomes for groups of different origins, there is much less agreement regarding the policies, programs, and strategies best suited to achieve these objectives, especially the degree to which they should recognize pluralism (Lorcerie 2003; McAndrew 2007).

The main goal of the special issue is to understand better the dynamics of integrating Islam and Muslim minorities within the educational systems of older and younger pluralistic societies, examining reciprocal transformations that occur during

M. McAndrew $(\bowtie) \cdot$ A. Triki-Yamani

Université de Montréal, Montreal, QC, Canada

e-mail: marie.mcandrew@umontreal.ca 
this process. Two issues are discussed: the adaptation of norms, programs, and practices of public schools to the needs of Muslim students, and the evolution of the formal and real curriculum of Muslim private schools.

Such a theme constitutes an extremely important test case for exploring the dynamic relationship that exists between ethnicity and education, and between religious identity and education, which will be analyzed through the lens of the constructivist approach (Barth 1969), now dominant in both sociologies of ethnic relations and of the curriculum (Juteau 2000; Apple and Christian-Smith 1991; Cooper 1997). Indeed, on the one hand, events related to $9 / 11$ initiated a major shift in the debate regarding immigration that is sometimes leaning towards islamophobia, both in European societies where contact with the Muslim World is historical, often through a colonial past, and in countries of more recent immigration like Canada or the United States, which receive an increasing number of Muslim immigrants (Geisser 2003; Helly 2004). In other contexts, where the presence of Muslims has little to do with the dynamics of immigration (e.g., India) the delicate balance between religions have also become more complex (Karic 1997; Eaton 2000). On the other hand, Islam, perhaps more than other monotheistic religions, is currently experiencing some difficulty in defining its relationship to secularism and the presence of sizeable Muslim minorities in turn poses challenges to the secular assumptions of their host societies. The distinction between public and private space has been at the center of numerous internal debates and conflicts with the institutions of pluralistic societies inhabited by Muslims (Bennett 2005). On the educational scene, numerous conflicts related to the management of ethno-cultural, and religiocultural diversity, the majority of which concern Muslim students, have thus touched public schools of secular societies, as they face increasing demands to adapt their norms and practices (Lorcerie 2005; McAndrew 2006).

The themes covered by this special issue are also at the crossroads of two very important preoccupations of decision-makers. On the one hand, how and how far should we ensure institutional adaptation to the needs of Muslim students in a context where both islamophobia and religious radicalism are increasing? On the other hand, how can we maximize the contribution of education to the improvement of intercultural and interfaith relations and to the production of a more equitable society?

One of the strengths of this special issue is its comparative perspective. In the first section, we are contrasting the adaptation of public schools to the needs of Muslim students in four societies, England, Ontario, Quebec, and France, which have adopted different models of citizenship and intercultural relations, more or less accommodating to diversity (on a continuum, antiracism, multiculturalism, interculturalism and republicanism, with some nuances we have to overlook here). In the first article entitled, Including the Religious Viewpoints and Experiences of Muslim Students in an Environment that is Both Plural and Secular, Julia Ipgrave reflects on the underlying factors that influence the educational inclusion and success of pupils of Muslim faith within mainstream education settings in England, and contrasts two different approaches in this regard. In the second paper, Teachers and Teaching Islam and Muslims in Pluralistic Societies: Claims, Misunderstandings, and Responses, after deconstructing some of the current perceptions regarding bias and stereotypes among mainstream teachers, Sarfaroz Niyozov argues for the necessity of greater critical engagement with their voices and practices in the education of Muslim minority 
students in Ontario. In her paper, The Muslim Community and Education in Quebec: Controversies and Mutual Adaptation, Marie McAndrew also stresses the hiatus that often exists between the visibility of some controversies targeting the Muslim community and education, taking Quebec as an example, and the actual mutual adaptation discreetly and slowly happening at the grassroots level. While the three last papers overall present a picture that allows for some positive expectations for the future, Françoise Lorcerie's paper, A French Approach to Minority Islam? A Study in Normative Confusion, concludes on a more pessimistic note. She describes the important hiatus between the normative republican model and the reality lived in schools both regarding the ad hoc adaptation to difference and the existence of discrimination and segregation linked to the ethno-cultural or religious origins of the students.

The second section explores the transformation of the curriculum of Muslim schools in Britain, India, and Ontario, as well as the identity they transmit to students, in response to the normative requirements of the mainstream society in which they are situated. The first article, Responses of Three Muslim Majority Primary Schools in England to the Islamic Faith of Their Pupils, written by Julia Ipgrave, Paul Hopkins, and Joyce Miller, compares three primary schools focusing on how teachers and school principals see Islam, taking into account their pupils' faith, and how they prepare pupils to live in a religiously plural Britain. In the second article, The Role of Indian Madrasahs in Providing Access to Mainstream Education for Muslim Minority Students: A West Bengal Experience, Najma Akhtar and Manju Narula, describe how the Madrasah Education System operates in West Bengal and the impact that its recent modernization has had on access to and quality of education for Muslim students. Finally, Nadeem Memon's Research note, Social Consciousness in Canadian Islamic Schools?, explores how some Canadian Islamic schools are making a more explicit attempt to create a space for the teaching of social justice through fundraising, dialogue, and community activism. These three societies were not chosen for their comparative macro relevance but because intensive ethnographic studies had been conducted of the functioning of such institutions, where it is often difficult to carry out research.

The articles included in this special issue already elicited a great deal of interest as well as many exchanges between university researchers and a varied audience composed of decision-makers at the federal and provincial levels, people involved at different levels of the school system, and NGO representatives, when they were presented at the colloquium on Islam and Education in Pluralistic Societies, held in Montreal in May 2008 (supported by SSHRC and the Department of Canadian Heritage). Since that event, through intensive collaboration with the authors as well as through a careful external peer review process, the quality of each paper and their overall complementarity has been enhanced. We wish to thank in this regard all the anonymous reviewers for their thoughtful considerations and criticism of the various contributions as well as the authors for their openness to suggestions and improvement. We are now firmly confident that this special issue will be of great interest for each person interested to the question of education and ethnic relations, as it relates specifically to Muslim minority students, and will contribute to knowledge and public policy development on migration and diversity in Canada and in other pluralistic societies. 
Acknowledgment In the production of this special issue, we would like to acknowledge the support of the following institutions: The Social Sciences and Humanities Research Council of Canada (SSHRC) and the Department of Canadian Heritage which funded the Colloquium "Islam and Education: Integration and Transformations in Pluralistic Societies" held in Montreal in May 2008 as well as part of this volume, and the Centre Metropolis du Québec, Immigration et métropoles, which specifically supported the production of this issue. Thanks should also be given to Patrice Brodeur, the Canada Research Chair on Islam, Pluralism and Globalization, University of Montreal, who co-organized the colloquium with Marie McAndrew, the Canada Research Chair on Education and Ethnic Relation (both supported by SSHRC), as well as to the colleagues in Canada and in Europe who accepted to peer review the articles.

\section{References}

Apple, M. W., and Christian-Smith, L. K. (1991). The politics of textbook. In M. Apple, \& L. K. Christian-Smith (Eds.), The Politics of Textbook (pp. 1-21). Routledge: Chapman and Hall.

Ballantyne, J. H. (1989). The sociology of education: a systematic analysis. Englewood Cliffs: Prentice Hall.

Barth, F. (1969). Ethnic groups and boundaries. Boston: Little, Brown.

Bennett, C. (2005). Muslims and modernity: an introduction to the issues and debates. London: Continuum.

Cooper, B. (1997). Comment expliquer les transformations dans les matières scolaires. In G. Fourquin (Ed.), Présentation et choix de textes (pp. 202-224). Paris/Bruxelles: De Boeck-Université.

Dei, G., James, I. M., James-Wilson, S., Karumanchery, L., \& Zine, J. (2000). Removing the margins: the challenges and possibilities of inclusive schooling. Toronto: Canadian Scholars' Press.

Eaton, R. M. (2000). Essays on Islam and Indian History. New Delhi: Oxford University Press.

Geisser, V. (2003). La nouvelle islamophobie. Paris: Éditions la Découverte.

Helly, D. (2004). Flux migratoires des pays musulmans et discrimination de la communauté islamique au Canada. In U. Manço (Ed.), Reconnaissance et discrimination. Présence de l'islam en Europe occidentale et en Amérique du Nord (pp. 257-288). Paris: L'Harmattan.

Holmes, B. (1981). Comparative education: some considerations of method. London: Allen and Unwin.

Homan, R. (1992). Separate schools. In J. Lynch, C. Modgil, \& S. Modgil (Eds.), Cultural diversity and the schools, volume one: education for cultural diversity: convergence and divergence (pp. 59-72). London: Falmer.

Juteau, D. (2000). L'ethnicité et ses frontières. Montréal: Presses de l'Université de Montréal.

Karic, E. (1997). Islam in contemporary Bosnia, a personal statement. Islamic Studies, 36(3), 477-482.

Krashen, S. (1996). Under attack: the case against bilingual education. Callvercity: Language Education Associates.

Lorcerie, F. (2005). La Politisation du voile-en France, en Europe et dans le monde arabe (Ed.). Paris: L'Harmattan.

Lorcerie, F. (2003). L'école et le défi ethnique, Education et intégration. Paris: ESF éditeur.

McAndrew, M. (2007). The education of immigrant students in a globalized world: policy debates in a comparative perspective. In M. Suarez-Orozco (Ed.), Global understandings: learning and education in troubled times. Berkeley/London/New York: University of California Press/ Ross Institute.

McAndrew, M. (2006). The hijab controversies in Western public schools: Contrasting conceptions of ethnicity and ethnic relations. In S. Rahnema et H. Moghissi (Eds.), The Making of the Islamic Diaspora. Toronto : University of Toronto Press.

McAndrew, M. (2001). Immigration et diversité à l'école. Le débat québécois dans une perspective comparative. Montréal: Presses de l'Université de Montréal. 